\title{
To What Extent the Social Counselors Use Theoretical Approaches in Practicing Counselling at Schools?
}

\author{
Al-Sabbah, Saher ${ }^{\text {a*} ; ~ C h i h a d a, ~ L a m a * ; ~}$ \\ ${ }^{a}$ Department of Psychology, Fatima College of Health Sciences, Abu Dhabi City, UAE, ORCID ID: https://orcid.org/0000-0001- \\ 8396-0063; ${ }^{\mathrm{b}}$ Department of General Requirements, Fatima College of Health Sciences;
}

\begin{abstract}
This study aimed to investigate the extent of practicing counselling techniques based on theoretical background by the social counselors in the Jordanian schools. In addition, the study targeted to investigate the impact of experience, gender and educational qualification variables on the counselling process. The researchers used a questionnaire consists of 37 items in three different components; theoretical background and knowledge, integration and practical skills, and challenges. The researchers examined the reliability and validity of the questionnaire by conducting a pilot study of a small sample that contained 15 social counsellors from the study's population. The study's sample consisted of 347 participants from 22 directorates, which are located in the northern, the central and the southern of Jordan. The SPSS statistical package Edition $23^{\text {rd }}$ was used to analyze the quantitative data in this study, and the method of analysis which is used in this analysis is descriptive statistical analysis and One and Two Way ANOVA. The results indicated that there is a lack of knowledge and understanding of counselling theories, the educational level was significant in reflecting the practicing of counselling theories and techniques. In addition, the study indicated that there are some obstacles hindering the social counsellors from practicing professional counselling skills at schools due to lack of workshops in addition to the big gap between theories and practice.
\end{abstract}

Keywords:

Social counselling, counselling theories, counselling techniques, counselling challenges.

Article Received: 18 October 2020, Revised: 3 November 2020, Accepted: 24 December 2020

\section{Introduction}

The Psychological Counselling is one of the most important types of applied psychology and it is used widely in schools, institutions, clinic, colleges and universities (Theodoros, 2005). The theories of counselling provide social and psychological counsellors with verity of techniques that could be used in counselling and psychotherapy sessions and treatment (NelsonJones, R, 2000). Each theory of counselling has different approaches, and most if not all the theories focused on the relationship between the counsellor and the client and specific procedures are used in practice of counselling. Many researchers indicated that there is a big gap between theories and practice in the field of counselling specially in schools (Nkechi Theresa, Egenti. 2016).

A mixture of theories approaches, can be one of the reasons in failing to adopt counselling theories due to the difficulties of finding the best practice of each theory. Schools' social and psychological counselors might need to get professional training before practicing counselling. Each therapeutic technique has valid dimensions and there is not an idealistic theory that fits all the client's cases and problems (Kourkoutas, Elias \& Giovazolias, Theodoros, 2015). A professional counselor needs to have enough knowledge and understanding of the human behavior and the theories approaches and implications for the social and psychological counseling (Tannous, Adel, 2012).

This study focuses on the theories of counselling and their practice by social schools' counselors in Jordan. The study will provide readers with a comprehensive understanding on the degree of practicing theoretical approaches and techniques in schools and the challenges they faced.

\section{Psychotherapy Theories}

There are several counselling and psychotherapy theories that are used in psychology. Many of these theories emphasize on the therapist-client relationship and the understanding of client's 
behavior and problems (McMahon, Mason., \&Paisley, O.P, 2016). The psychoanalytic theory, that is found by Sigmund Freud, focuses on the unconscious of client as a motivate of human behavior as a basic element of personality. The psychoanalytic theory explained the relationship between ID, Ego and Superego, then analyzed the conflict between the individual's values and desires. In Freud Theory, the childhood stages of development during which the ID's pleasure seeking energies focused on different parts of the body. The stages include. oral, anal, phallic, latency, and genital. A person can become fixated or stuck at a stage. The psychoanalysis techniques in Freud's theory focus on four methods; free association, dream analysis, interpretation and confrontation and clarification (Scarborough, L. J, 2015).

Another theory of counseling is Adler Theory who paid attention to the nature of human as a positive view to understand the way we react towards different life situations and scenarios. He insisted that as humans we can decide our life path and control our fate. The social interest is a main component in Adlerian Theory as it plays a crucial role in forming our relationships with others and this will lead to success at a personal level. The interaction between individual with family, teachers, friends and society members can help to determine the role of inferiority and superiority in a person's live (Nweze \& Okolie, (2014). In Adler Theory, there are four phases of psychotherapy techniques; phase 1: establish relationship, listening skills, winning respect and offering hope and encouragement; phase 2: analysis and assessment, phase 3: promoting insight and phase 4: Re-orientation.

As for the Behavioral Theory techniques, it has been found by Aaron Beck who stressed on client's present thinking and feeling, behavior, and communication instead of focusing on the past experiences. This theory focuses on helping clients to solve their problems. The most notably in his theory is the Beck Depression Inventory (BDI). The theory aimed to change the clients' dysfunctional beliefs that predispose them to distort experiences based on a principle that they hold against their life events through a combination of factors, such as cognitive, behavioral, motivational, and affective responses (Life Strategies, 2013).

In the Gestalt Theory, Fritz Perls focuses on the principle that a person should focus on the present time rather than back to the past experiences. Psychologists and counselors need to emphasize on their clients to view themselves as a whole entity which consists of three components; mind, soul and body rather than looking back into the past by bringing the past into the present (Guberman, Shelia. 2015).

\section{School Counselling}

School counselling is a process that involves an educated and professional counselor who works in different levels of schools; elementary, middle, and high schools to provide academic, career, and college access, and personal/social competencies Alkhazaleh, Z.M., \& Alharbi, B. (2017).

The school counsellor plays a major role in monitoring the students' behavior by providing a proper intervention in different aspects; developmental, curriculum, lesson plan, bad habit, individual and group counselling, and annual planning for the counselling program involving a plan for every student.

Students' number at school, support services and the family commitment towards counselling play a major role in the success of the school counselling program. Social and psychological counselors need to comply to their job description instead of doing other staff tasks in the school by focusing on action research, consultation with parents, teachers and staff. Besides, counselors need to work closely with the community agencies and to pay attention to diversity and individual differences. Counselors are expected to promote educational, vocational, social, and personal development, and the average ratio number of students and counselors should be 1:250.

\section{Method}

\section{Research Design}


The mixed research design was used in this study; qualitative and qualitative data. The researchers in this study developed a questionnaire consists of 37 items to collect the quantitative data from the study's percipients. As for the qualitative data, a constructed interview including three main questions was used to interview 10 counselors from different regions in Jordan.

\section{Study Questions}

1. To what extent the school counselors in Jordan practicing theoretical-based counselling?

2. Do the school counselors in Jordan have sufficient knowledge of counselling theories?

3. Are the school counselors have the ability and skills to integrate counselling theories and techniques into their counselling sessions?

4. What are the challenges the school counselors face in Jordan?

5. Are there any statistical differences between the counselors' responses in terms of gender, years of experience, and the academic qualification variables?

\section{Study Sample}

The study used a cluster sample by selecting 22 educational directorates from the Northern, Southern and Central of Jordan. 8 directorates were selected from the Northern Region, 10 from Central Region, and 4 from the Southern Region of Jordan. A random sample selection of schools from each directorate was done in order to have a comprehensive sample from the three regions of Jordan. A total number of 347 counselors was selected to form the final number of sample of this study.

\section{Data Analysis:}

In order to analyze the study data, the researchers used the SPSS Program to analyze the quantitative data, and the analysis used is descriptive analysis and one-way ANOVA. As for the qualitative data, the researchers interviewed a number of 10 counselors and the responses were analyzed and organized by highlighting the themes of responses.

\section{Validity and Reliability}

To validate the study tool, the researchers in this study created an initial draft of questionnaire consists of 43 items in three different domains. The questionnaire then was sent to 4 experts in the field of psychology, education and counselling for content and face validity. The results indicated that there were 11 items to be modified, 6 items to be removed and 3 items to be replaced, and the final questionnaire with 37 items was formed. A pilot study was conducted on a small number of participants in order to compute the correlation coefficient using Cronbach's Alpha and the results showed that the whole scale reliability is 89.7. As for the three subscales, the results indicated that the reliability of the first subscale is 85.3 , second subscale is 88.01 and the third subscale is 87.5 .

Table 1:1 The Cronbach's Alpha for the whole scale and the subscales

\begin{tabular}{|c|c|c|c|}
\hline No & Domains & $\begin{array}{l}\text { Number of } \\
\text { Items }\end{array}$ & Cronbach's Alpha Value \\
\hline 1 & $\begin{array}{l}\text { Theoretical } \\
\text { background and } \\
\text { knowledge }\end{array}$ & 13 & 85.3 \\
\hline 2 & $\begin{array}{l}\text { Integration and } \\
\text { practical skills }\end{array}$ & 12 & 88.01 \\
\hline 3 & Challenges & 12 & 87.5 \\
\hline Total & Whole scale & 37 & 89.7 \\
\hline
\end{tabular}




\section{Findings}

The findings in this study are divided into two parts; quantitative and qualitative:
The first part of the findings is used to answer question one of this study; "to what extent the school counselors in Jordan practicing theoreticalbased counselling?".

\section{First: Quantitative Part}

Table 1.2 The Means and Standard Deviations of Overall Scale Items; highest and lowest items

\begin{tabular}{|c|c|c|c|c|}
\hline $\begin{array}{l}\text { Item Number } \\
\text { as in the } \\
\text { questionnaire }\end{array}$ & Item & domain & Mean & (SD) \\
\hline 3 & $\begin{array}{l}\text { I have sufficient knowledge on most of } \\
\text { the counselling theories }\end{array}$ & 1 & 3.04 & 0.94 \\
\hline 24 & $\begin{array}{c}* \text { Lack of workshops and practical } \\
\text { training }\end{array}$ & 3 & 4.04 & 0.95 \\
\hline 28 & $\begin{array}{l}\text { *My school management don't support } \\
\text { me in my counselling tasks }\end{array}$ & 3 & 4.03 & 1.21 \\
\hline 30 & $\begin{array}{c}\text { *My school's principal assigns me } \\
\text { more admin works }\end{array}$ & 3 & 3.6 & 1.09 \\
\hline 11 & $\begin{array}{l}\text { I know how to integrate the } \\
\text { counselling theories into my work }\end{array}$ & 1 & 2.59 & 1.03 \\
\hline 35 & $\begin{array}{l}\text { The big number of students in the } \\
\text { school impairs me to conduct } \\
\text { individual counselling }\end{array}$ & 3 & 4.19 & 1.09 \\
\hline 17 & $\begin{array}{l}\text { I have enough skills on applying } \\
\text { theories techniques in my school } \\
\text { counselling }\end{array}$ & 2 & 2.81 & 1.08 \\
\hline 21 & $\begin{array}{l}\text { I know how to select the right } \\
\text { techniques in my counselling cases }\end{array}$ & 2 & 2.89 & 1.01 \\
\hline Total & & Overall & 3.5 & 1.01 \\
\hline
\end{tabular}

\section{Overall Scale}

The findings of the first part of this study indicated that counselors do not have enough knowledge about the counselling theories and techniques, and they face some challenges in their work, such as the lack of training and workshops, due to a huge number of students in their schools, which is impair them to perform their counselling tasks, and involving themselves in admin work instead of carrying out the counselling ones.

First Domain: Theoretical Background and Knowledge
The findings of the first domain in this study reported that there is a lack of knowledge on the counselling theories and techniques, as some of the counselors do not have a sufficient theoretical background and they are practicing some tasks which are irrelevant to their counselling work because the management at their schools do not encourage them to practice counselling. In addition, some of the counselors have sufficient knowledge on counselling theories, however, they lack knowledge on how to use the counselling techniques because they don't receive a guidance from their supervisors. 
Second Domain: Integration and Practical Skills

The findings related to the second domain in this study reported that the counselors lack skills on how to apply the counselling theories on their individual and group counselling. Counselors do not know how to select the right techniques for each individual case, and they lack the training on how to apply such techniques in counselling hindered them from performing their job asks as counselors.

Third Domain: Challenges

The findings indicated that there are some challenges that school counselors face in Jordan such as, time given to counselling as many counselors do regularly administrative work at schools instead of doing the counselling tasks, less encouragement from the school principal and Gender variable

Table 1.3: Output of One-Sample T-test for Male and Female on Practicing Counselling Theories

\begin{tabular}{lcccc}
\hline \multicolumn{1}{c}{ T-test } & N & Mean & Std. Deviation & Sig. \\
\hline Male & 121 & $\mathbf{3 . 3 9 4 2}$ & .40459 & .000 \\
Female & 226 & $\mathbf{4 . 1 4 4 2}$ & .54680 & .000 \\
Valid N (list wise) & 226 & & & \\
\hline
\end{tabular}

The above table indicated that there is statistically a significant difference between male and female while practicing the counselling theories at schools, and the female counselors showed more positive attitude towards integrating and practicing those theories on their individual and group counselling.

Gender and Qualifications Variable

Table 1:4 Two-Way ANOVA analysis for the differences between gender and qualifications variables of counsellors participated in the study

\begin{tabular}{lccccc}
\hline \multicolumn{1}{c}{$\begin{array}{c}\text { Variables } \\
\text { Gender and } \\
\text { Qualifications }\end{array}$} & $\begin{array}{c}\text { Type III Sum } \\
\text { of Squares }\end{array}$ & Df & Mean Square & F & Sig. \\
\hline Corrected Model & $.844 \mathrm{a}$ & 4 & .211 & 1.321 & .276 \\
Intercept & 259.704 & 1 & 259.704 & 1626.463 & .000 \\
Gender & .031 & 1 & .031 & .192 & $\mathbf{. 6 6 3}$ \\
Qualifications & .745 & 2 & .372 & 2.332 & $\mathbf{. 1 0 8}$ \\
Gender * Qualifications & .112 & 1 & .112 & .705 & $\mathbf{. 4 0 6}$ \\
Error & 7.505 & 342 & .160 & & \\
Total & 607.430 & 347 & & & \\
Corrected Total & 8.348 & 346 & & & \\
\cline { 1 - 2 }
\end{tabular}

a. R Squared $=.101$ (Adjusted R Squared $=.025$ ) 
The above table shows that there is not any statistically significant differences between the gender and the level of qualifications as at $\mathrm{P}$ value of .05 .

Years of Experience Variable

Table 1.5: Descriptive statistics and one-way ANOVA for a year of experience variable

\begin{tabular}{ccccccc}
\hline Year of Experience & $\mathrm{N}$ & Mean & Std. Deviation & Mean Square & F & Sig. \\
\hline Below than 5 year & 115 & 3.8768 & .51381 & & & \\
6 to 10 year & 90 & 3.7676 & .46253 & & & \\
11 to 20 year & 83 & 3.6929 & .30246 & & & \\
More than 20 year & 59 & 3.5687 & .39110 & & & \\
Between Groups & & & & .452 & 2.097 & $\mathbf{. 1 0 3}$ \\
Within Groups & & & & .216 & & \\
\hline
\end{tabular}

The above table shows that statistically there is not a significant difference between the years of experience on the responses of counsellors on the questionnaire items. The output of this comparison showed that the difference value is less than $\mathrm{P}$ value 0.05 , which means the years of experience variable is not effective on practicing counselling theories at schools.

\section{Second: Qualitative Analysis}

The interviews were conducted on 10 counsellors from a random sampling from school counsellors in Jordan. The results from the interviews showed general themes from the three domains of the study questionnaire; the knowledge and understanding of counselling theories, integration of counselling techniques and skills, and the challenges counsellors face in their school counselling. The overall results indicated that the main obstacle in performing professional counselling in schools is due to the misunderstanding of counsellor's roles in schools by school's management and teachers. Many schools principals do not give full support to facilitate the counselling progress at schools. Moreover, counsellors face hard time in their relationship with the school principals who request them to accomplish mpre administration work rather than the counselling duties. In addition, the training and workshops which are provided by the Ministry of Education are more to theoretical perceptive than practical ones. Besides, the family involvement in the counselling process is really poor and it need to be more organized and structured to enrich the school counselling and to achieve the targeted goals of counselling.

\section{Conclusion and Recommendations}

The main results of this study highlighted the importance of having a comprehensive counselling programs across schools and directorate in Jordan aiming to improve the counselling approaches, counselling services, counselling workshops and training. This result corresponded with Alkhazaleh, Z.M., \& Alharbi, B. (2017) and Raed (2018) who indicated that there is a need to have strategical ad organized plan for counselling in the country. On the other side, counsellors need more professional development on the counselling strategies and techniques. There is a need to improve and introduce more criteria for hiring social and psychological counsellors at schools. This results indicated that one of the most important challenges for social counsellors is the family engagement in the counselling process as many parents do not pay attention or follow up with their children's school progress.

\section{Recommendations:}

The researchers in this study recommend the following: 
- The Ministry of Education is suggested to revise all the counselling workshops and training courses to focus more on the application of counselling theories used in the individual and group counselling.

- The relationships between the school counsellors and their principals should be more organized and that could be achieved through clear regulations and guidance.

- Based on the capacity and the huge number of students at schools, it is recommended to recruit more counselors (the ration of counselor and student number should be 1:250).

\section{REFERENCES}

[1] Ahmad, Raed. (2018). The role of the vocational guidance toward the technical education. (Master thesis). Albalqa' Applied University. Amman, Jordan.

[2] Alkhazaleh, Z.M., \& Alharbi, B. (2017). Knowledge Fields in School Counselling at a Sample of Counselling Students in the Jordanian Universities Accordance of Some Variables.

[3] Kourkoutas, Elias \& Giovazolias, Theodoros. (2015). School-Based Counselling Work With Teachers: An Integrative Model. European Journal of Counselling Psychology. 3. 10.5964/ejcop.v3i2.58.

[4] Life Strategies. (2013). Skill requirements for BC's career development practitioners: An exploratory study. Vancouver, British Columbia, Canada: BC Centre for Employment Excellence. Retrieved from: http://www.cfeebc.org/reports/skillrequiremen ts-for-BC-career-developmentpractitioners.pdf

[5] McMahon, G. H., \& Mason, M. C. E., \& Paisley, O. P. (2016). School counseling for the 21th Century: challenges and opportunities

[6] Nelson-Jones, R. (2000). Six key approaches to counselling and therapy. Second Edition. https://www.amazon.com/Six-Key-

Approaches-Counselling-

Therapy/dp/0857024000
[7] Nkechi Theresa, Egenti. (2016). The role of Guidance and Counselling in effective teaching and learning in schools.

[8] Nweze, T., \& Okolie, Ch. U. (2014). Effective Guidance and Counseling Programs in Secondary Schools: Issues and Roles in Students' Career Decision Making. OSR Journal of Research \& Method in Education (IOSR-JRME) e-ISSN: 2320-7388, p-ISSN: 2320-737X, Volume 4, Issue 4 Ver. V, 63

68, www.iosrjournals.org

[9] Garald Corny (2015). Theory and Practice of Counseling and Psychotherapy, California State University, Fullerton, ISBN-13: 978-0495-10208- Retrieved from: https://yuliaaziz09.files.wordpress.com/2015/0 6/theory and practice of counseling and ps ychotherapy.pdf

[10] Giovazolias, Theodoros. (2005). Counselling in Action, Counselling psychology and the integration of theory, research and practice: A personal account. Counselling Psychology Quarterly. 18. 161-168.

[11] Guberman, Shelia. (2015). On Gestalt Theory Principles. Institute of Applied Mathematics Russian Academy of Sciences. Retrieved from:

file://C:/Users/saher.alsabbah/Downloads/On Gestalttheoryprinciples.pdf

[12] Tannous, Adel \& AlKhateeb, Jamal \& Alkhamra, Hatem \& Hadidi, Muna \& AlNatour, Mayada. (2012). Jordanian School Counselors' Knowledge About and Attitudes Toward Diabetes Mellitus. International Journal for the Advancement of Counselling. 34. 10.1007/s10447-011-9143-3.

[13] Scarborough, L. J. (2015). The School Counselor Activity Rating Scale: An Instrument for Gathering Process Data. Research Gate https://www.researchgate.net/publication/2346 $\underline{68179}$ 